\title{
Arheologija spomina: primer Rodika
}

\author{
Massimo Medeot
}

Društvo Limes arheologija prostora

massim01938@gmail.com

Mario Crevato

Društvo Limes arheologija prostora

m.crevato@gmail.com

\begin{abstract}
Alja Margon
Društvo Limes arheologija prostora

amargon77@gmail.com
\end{abstract}

\section{Uvod}

Območje Brkinov in Matarskega podolja je bilo poseljeno že v prazgodovini, vendar je do kolikor toliko stalne poselitve najverjetneje prišlo šele $\mathrm{v}$ predzgodovini. Iz tega obdobja izhajajo tudi prve znane utrdbe na tem območju. Šlo je predvsem za t.i. gradišča z enim ali več obrambnimi nasipi, ki so zaradi svojih mogočnih ostankov pritegnila pozornost raziskovalcev že v 19. stoletju. V tej točki velja nujno omeniti Carla de Marchesettija, ki je gradiščem s tega območja namenil celo knjigo (1903).

Po osvojitvi s strani Rimskega cesarstva in posledični romanizaciji prebivalstva so nastala nova naselja in obrambe strukture, predvsem pa razvejano cestno omrežje, ki se je deloma opiralo tudi na že obstoječe predzgodovinske poti. Proti koncu rimskega obdobja, torej v pozni antiki, pa je prišlo tako do ponovnega poseljevanja predzgodovinskih kot tudi do nastanka novih utrjenih naselij. Na podlagi arheoloških in ustnih virov lahko sklepamo, da je tak tip poselitve trajal več stoletij, tj. vsaj do začetka zgodnjega srednjega veka.

$\mathrm{V}$ pričujočem sestavku namerava društvo Limes - arheologija prostora predstaviti arheološka najdišča na območju Mitskega parka Rodik. Park namreč v sebi skriva številne ostaline iz preteklih zgodovinskih obdobij, ki so pestre tako po starosti nastanka kot tudi po tipologiji.

\section{Metodologija}

Pri pisanju tega sestavka smo se sicer opirali na »klasične« bibliografske in kartografske vire, vendar se je na koncu izkazala za ključno obdelava 
in uporaba podatkov, pridobljenih s pomočjo metode lidar (iz angleškega Light Detection And Ranging, v dobesednem prevodu svetlobno zaznavanje in merjenje). ${ }^{1}$ Ta metoda omogoča izredno natančno merjenje zemeljskega površja s pomočjo posebnih laserjev in sprejemnikov, nameščenih na letalo, helikopter ali dron. Laserski žarek je usmerjen proti tlom in se od njih odbija. Čas, ki je potreben, da se odboj oddanega žarka vrne do sprejemnika, omogoča izredno natančen izračun razdalje od tal. S pomočjo sistema GPS je nato mogoče natančno določiti tridimenzionalne koordinate vsake izmerjene točke. $S$ pomočjo lidarja je tako mogoče dobiti jasno sliko zemeljskega površja in vseh "tujkov«, ki se nahajajo na njem. Ker lahko laserski žarek prodre tudi skozi vegetacijo, lidar omogoča natančno kartiranje tudi močno zaraščenih območij.

Lidar se je na področju Rodika izkazal za izredno dragocen pripomoček. Klasični letalski in satelitski posnetki namreč raziskovalcu ne omogočajo zadovoljivega vpogleda v situacijo na terenu, saj je območje pretežno poraščeno $z$ gozdom. Lidar deluje vegetaciji navkljub in izkušenemu raziskovalcu omogoča, da opazi vse posebnosti na zemeljski površini in tako postane dragoceno orodje za izvajanje arheoloških raziskav. S pomočjo lidarja je namreč mogoče jasno določiti tako izbočene (ostanki zidov, gomil, nasipov) kot tudi vbočene (jarki, poglobitve, prekopi) strukture antropogenega izvora (Mlekuž 2012). Pri interpretaciji posameznih površinskih struktur pa je seveda potrebna velika mera samokritičnosti, saj se rado zgodi, da neizkušen raziskovalec strukturo povsem naravnega izvora zamenja za delo človeških rok. Seveda pa ima tudi ta metoda svoje omejitve. Meritve so tako manj natančne na območjih, ki so geološko gledano mlajšega izvora, še posebej, če so poleg tega prekrita še z gozdom. Na žalost spadajo Brkini zaradi svoje flišnate narave in zaraščenosti ravno v to kategorijo. Problem smo rešili s temeljito dodatno reelaboracijo sicer javno dostopnih podatkov. Istočasno $\mathrm{z}$ računalniško elaboracijo je potekalo tudi preverjanje dejanskega stanja na terenu. To večkrat odstopa od opisov v bibliografskih virih, ki so včasih že kar spoštljive starosti. Vzrok so tako novejši antropogeni posegi kot tudi pomanjkljivosti in nenatančnosti v samih zapisih. Poleg tega je potrebno upoštevati tudi, da je v zadnjih 100 letih naravno okolje na območju Krasa in Brkinov doživelo nadvse dramatično preobrazbo.

${ }^{1}$ Lidarski posnetki za celotno Slovenijo so javno dostopni na spletni strani Agencije Republike Slovenije za okolje (http://gis.arso.gov.si/atlasokolja/profile.aspx?id=Atlas_Okolja _AXL@Arso). Od tam smo vzeli tako izvorne podatke kot tudi nekatere posnetke, ki smo jih uporabili v tem sestavku. 


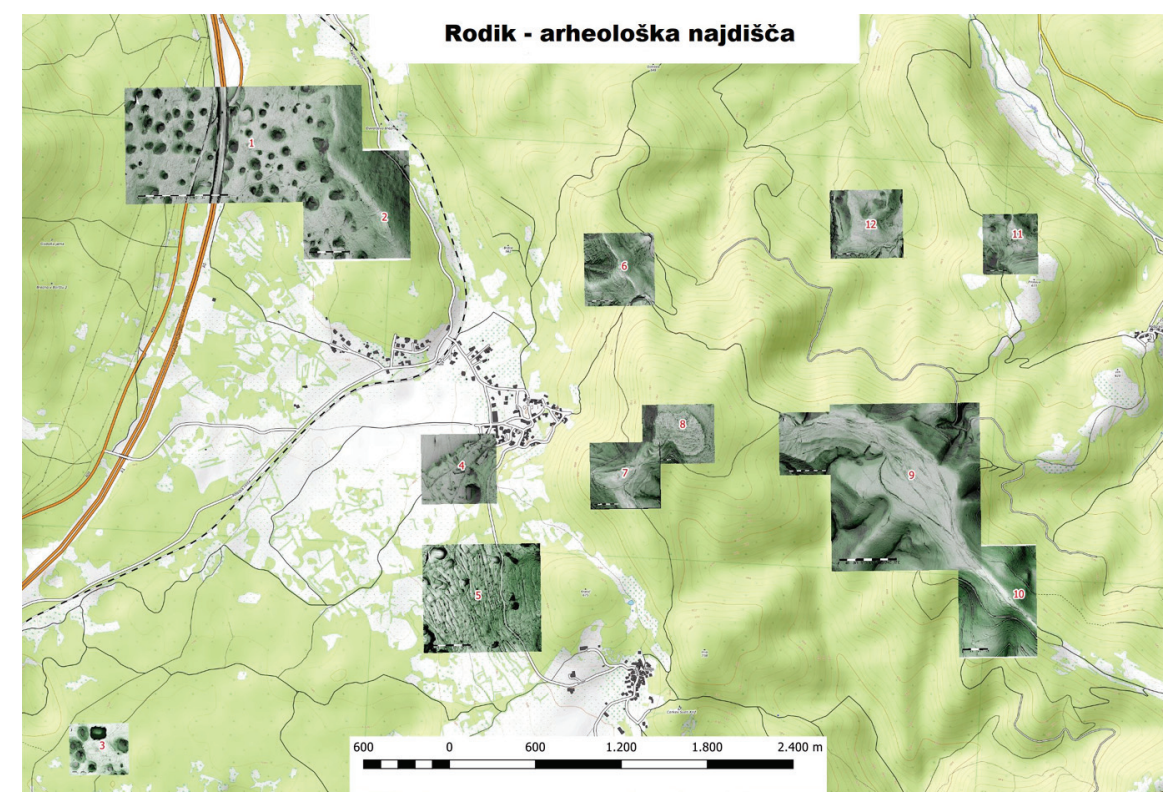

Slika 1 Lidarski prikaz obravnavanih lokacij na topografski karti (1 - zaporni zid Gabrova stran, 2 - gradišče Gabrova stran, 3 - gradišče Debela griža, 4 - ledina Krvice, 5 - ledina Grubelce, 6 - Tabor, 7 - Čuk, 8 - gradišče Ajdovščina, 9 ledini Njivice in Vrhule, 10 - Križen drev, 11 - Pristava, 12 - Mešuce)

Nekoč gola pokrajina je zaradi pogozdovanja, opuščanja kmetijstva in odseljevanja prebivalstva dandanes večinoma prekrita $\mathrm{z}$ gozdom. Drevesa in grmičevje ne samo da zakrivajo pogled na nekoč od daleč opazne razvaline, ampak z razraščanjem svojega koreninskega sistema tudi pospešeno uničujejo ostanke zidanih struktur.

$\mathrm{V}$ tem sestavku se bomo osredotočili predvsem na manj znana in manj raziskana arheološka najdišča znotraj Mitskega parka Rodik, ob tem pa seveda ne bomo zanemarili tudi tistih bolj znanih in bolj raziskanih. ${ }^{2}$

\section{Spodnji del poti po Mitskem parku Rodik}

\section{Zaporni zid Gabrova stran}

Zaporni zid Gabrova stran smo odkrili člani društva leta 2019. Objekt smo natančno preučili in o naših dognanjih poročali Zavodu za varstvo kulturne

${ }^{2}$ Pri raziskavah smo porabljali uradno kartografijo Republike Slovenije, ki je javno dostopna na spletni strani (https://gisportal.gov.si/portal/apps/webappviewer/index.html) in javno dostopno zbirko starih zemljevidov v okviru projekta Mapire (https://mapire.eu/en/). 
dediščine (OE Nova Gorica), širša javnost pa z novim najdiščem do sedaj ni bila seznanjena. Zaporni zid se nahaja na območju, kjer so prisotni številni kraški pojavi, predvsem veliko število globokih vrtač. Suhih zidov na parcelnih mejah, ograd, kolovozov za dostop do parcel in drugih znakov ekonomske izrabe območja praktično ni. Iz Fanciscejskega katastra in iz dostopne avstrijske vojaške kartografije je razvidno, da vsaj od druge polovice 18. stoletja naprej na tem območju ni bil prisoten noben relevanten antropogen objekt in da je bilo koriščeno izključno kot gmajna, pašnik ali gozd. Možnost, da bi lahko šlo za moderen objekt, je torej izključena.

Ostanki zidu so na terenu večinoma slabo vidni. Verjetno je ravno to, poleg uničenja najdostopnejšega dolinskega dela zidu zaradi gradnje avtoceste, regionalne ceste in deloma tudi visokonapetostnega voda ter relativne oddaljenosti od naselij, botrovalo dejstvu, da zidu do sedaj še nihče ni opazil.

Po naših ocenah meri zid v dolžino približno $1.350 \mathrm{~m}$. Pri tem nismo upoštevali uničenega segmenta. Na odsekih, kjer je najbolj ohranjen, sega v višino do $50 \mathrm{~cm}$ nad siceršnji nivo tal, spet drugod so njegovi ostanki v nivoju s tlemi, vendar je iz z mahom poraščenih kamnov vidna linearna struktura. Variabilna je tudi širina ostankov. Na odsekih, kjer je zid najbolj ohranjen, je njegova širina približno 2,5 m, kjer pa je bolj razvaljen, dosega širino do 4,5 $\mathrm{m}$. Zid je bil sezidan iz večjih neobdelanih apnenčastih kamnov, ostankov malte pa nismo opazili.

Objekt teče v loku v smeri od zahoda proti vzhodu. Skrajna zahodna točka objekta se nahaja pod hribom Grmada, skrajna vzhodna točka pa se nahaja v sklopu arheološkega najdišča Gabrova stran. Graditelji zidu so odlično izrabili naravne danosti območja. Na nekaterih točkah so tako v zid vključene tudi večje na kraju naravno prisotne skale ipd., graditelji pa so koristno izrabili tudi prisotnost globokih vrtač, saj zid na več mestih teče čisto nad njihovim robom. Kar se same obrambne funkcije tiče, je iz terenskega ogleda več kot očitno, da je bil zid namenjen nadzorovanju prihodov s severa, torej iz smeri današnje Divače.

Približno $150 \mathrm{~m}$ severno od zapornega zidu smo med raziskavami opazili tudi manjšo zidano strukturo pravokotne oblike $(10 \times 15 \mathrm{~m})$, za katero mislimo, da bi bila lahko tako kot zid antičnega izvora. Na to nas napeljujeta tako bližina zidu kot tudi sama tehnika gradnje. Ostanki zidov segajo v višino do $30 \mathrm{~cm}$ nad siceršnji nivo tal in so široki $2-2,5 \mathrm{~m}$. Tehnika gradnje je enaka kot pri zapornem zidu.

Domnevamo, da gre za ostanke predzgodovinskega ali antičnega zapornega zidu. Kljub odsotnosti relevantnih arheoloških najdb, ki bi omogočale 


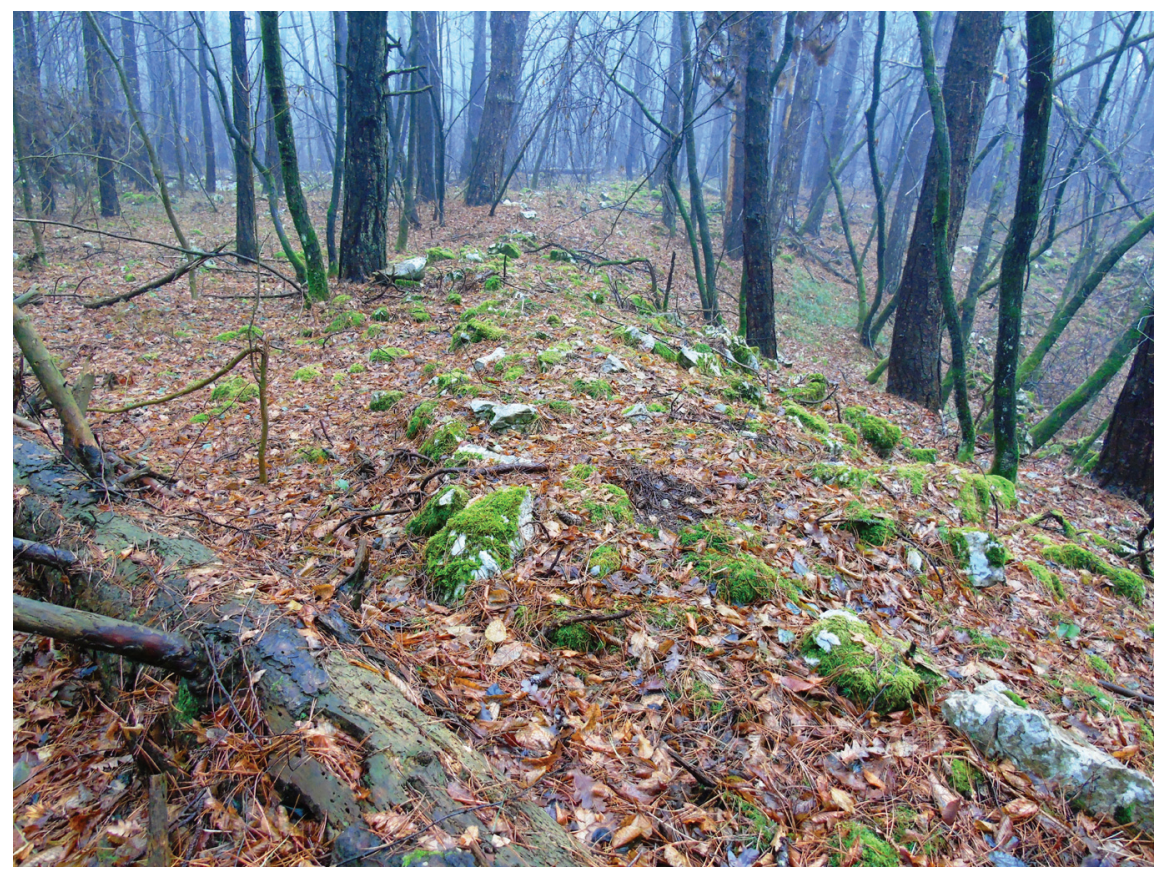

Slika 2 Zaporni zid Gabrova stran (avtor fotografije Društvo Limes)

natančno datacijo objekta, menimo, da lahko na tem mestu postavimo več hipotez. Razsežnost in oblika ohranjenih struktur dajeta misliti, da gre za objekt predzgodovinskega izvora (železna doba), vendar glede na najnovejša arheološka odkritja na območju Notranjske tudi ne gre izključiti možnosti, da izhaja iz rimskega obdobja. Vsekakor pa povsem izključujemo možnost, da bi lahko bili ostanki mlajši, torej srednjeveški, novoveški ali celo sodobni. Ne samo zaradi načina gradnje in slabe ohranjenosti, ampak predvsem zato, ker o morebitnih tovrstnih strukturah ni najti sledi ne $\mathrm{v}$ kartografiji ne $\mathrm{v}$ pisnih virih, ravno tako pa potek zidu ne sledi katastrskim, srenjskim ali občinskim mejam.

\section{Gabrova stran (E Š D 7281)}

Prazgodovinsko gradišč z ohranjenim obrambnim okopom. Notranjost je zakrasela, ohranjenost kulturne plasti ni znana. Lokacija grobišča ni znana. Datacija: pozna bronasta doba, železna doba. ${ }^{3}$

\footnotetext{
${ }^{3}$ Uradne opise arheoloških najdišč smo povzeli po Registru kulturne dediščine, ki je javno dostopen na spletni strani (https://www.gov.si/teme/register-kulturne-dediscine).
} 


\section{Slika 3}

Marchesettijeva risba gradišča

Gabrova stran (Marchesetti 1903, 80)

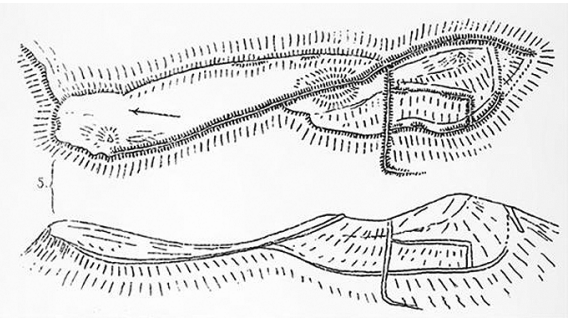

»Na Tretjem vrhu je bil enkrat velik grad« (Peršolja 2000, 45). Gradišče na hribu Gabrova stran (kota 6o9) je arheologom relativno dobro poznano. Da je na tem kraju zraslo veliko utrjeno naselje, ne preseneča. Naravni pogoji - dominanten položaj na vrhu vzpetine, prepaden teren na severnem in zahodnem delu, ki omogoča učinkovito obrambo, in prisotnost vodnih virov v neposredni bližini - so naravnost idealni.

Preučeval in kartiral ga je že Marchesetti, ki ga je opisal s sledečimi besedami $(1903,79-80):^{4}$

Gradišče obsega tri vrhove in je torej nezanemarljive velikosti. V dolžino meri 500 metrov, široko pa je od 60 do 100 metrov. Njegova zgradba je dokaj zapletena in je precej različna od splošno razširjenega tipa. Južna vrhova sta obkrožena z obrambnim okopom, ki je dolg 550 metrov, visok od o,5 do 1 metra in širok od 6 do 15 metrov. Na nekaterih kratkih odsekih okopa ni. Tako ograjeno območje deli na dva dela izrazit prečen nasip, ki se nadaljuje še kakšnih 40 metrov vzdolž brežine izven gradišča. Na zahodni strani so opazni ostanki še enega notranjega nasipa, ki pa je precej manj izrazit. Vzdolž hrbta, ki se nežno vzpenja proti severnemu vrhu, je na zahodni strani dobro viden 210-metrski obrambni okop. Na vzhodni strani, kjer je brežina zelo strma, je obrambni okop prisoten le v sledeh.

Celotno območje je bilo tekom 20. stoletja predmet intenzivnega vojaškega utrjevanja. Med prvo svetovno vojno so gradišče tako prepredli strelski jarki in manjši utrjeni položaji, gradnja vojaških objektov pa se je nadaljevala tudi v kasnejših obdobjih. Na žalost je bil pri tem uporabljen material, ki je bil najbolj pri roki, tj. kamenje iz obrambnih okopov gradišča. Zaradi tega so strukture, ki so bile pred dobrimi sto leti še dobro vidne,

\footnotetext{
${ }^{4}$ Marchesetti gradišče poimenuje »castelliere di Cacice«. Iz italijanščine prevedla Alja Mar-
} gon. 
močno poškodovane. Dandanes lahko na terenu ostanke gradišča prepozna le pozoren opazovalec.

Gabrova stran oz. utrdba na Tretjem vrhu je pustila sledi tudi v ustnem izročilu. Domačini govorijo, da je na Tretjem vrhu nekoč stal mogočen grad, v njem pa da je živel bogat in lakomen grof (Peršolja 2000).

\section{Gradišče Debela griža in bližnja jama z arheološkimi najdbami iz rimskega obdobja (E Š D 7278)}

Prazgodovinska utrjena naselbina, postavljena $v$ nižini sredi osmih kraških vrtač. Naravno obrambno lego dopolnjuje v celoti ohranjen kamnit obrambni okop izjemnih dimenzij. Severno od naselbine je spodmol (kevderc) z rimskodobnimi sledovi poselitve. Datacija: pozna bronasta doba, železna doba, rimska doba.

Gradišče Debela griža je Marchesetti $(1903,80)$ opisal s sledečimi besedami: ${ }^{5}$

V bližini stare ceste, ki od Rodika vodi proti Hrpeljam, najdemo nedaleč od le-te vasi gradišče, ki je posebno po tem, da je bilo zgrajeno praktično na ravnini. Obkroženo je s sedmimi globokimi vrtačami, največja meri v premeru kar 100 metrov in ima prepadne stene. Torej je bilo gradišče, kljub temu da ni stalo vrh vzpetine, zaradi pametno izkoriščenih naravnih danosti kraja, kjer je bilo zgrajeno, dobro zaščiteno. Nezaščitene predele med posameznimi vrtačami je branilo čvrsto ozidje, ki je bilo prvotno široko 2 metra. Potem ko se je razvalilo, se je tudi razlezlo v širino. Danes so tako nasipi široki od 8 do 15 metrov in so še vedno visoki od dveh do treh metrov. Gradišče ima obseg 450 metrov in je v notranjosti skoraj povsem ravno. Znotraj obzidja je tako lepa krožna planjava s temno prstjo, v kateri je moč najti tudi številne črepinje. Potrebno je tudi dodati, da se na dnu prej omenjene globoke vrtače nahaja velika in dobro osvetljena jama, ob katere vhodu se nahajajo ostanki zelo starega zidu. Pod prepadnimi stenami je opaziti tudi precej drugih zaklonov, ki dandanes sicer nudijo zavetje samo pastirjem, vendar so v preteklosti, če je to bilo potrebno, gotovo nudili varno pribežališče tudi prebivalcem gradišča.

\footnotetext{
${ }^{5}$ Marchesetti gradišče poimenuje »castelliere di Erpelle«; vrtač je v resnici osem. Iz italijanščine prevedla Alja Margon.
} 


\section{Slika 4}

Lidarski posnetek Debele griže (gradišče in osem vrtač)

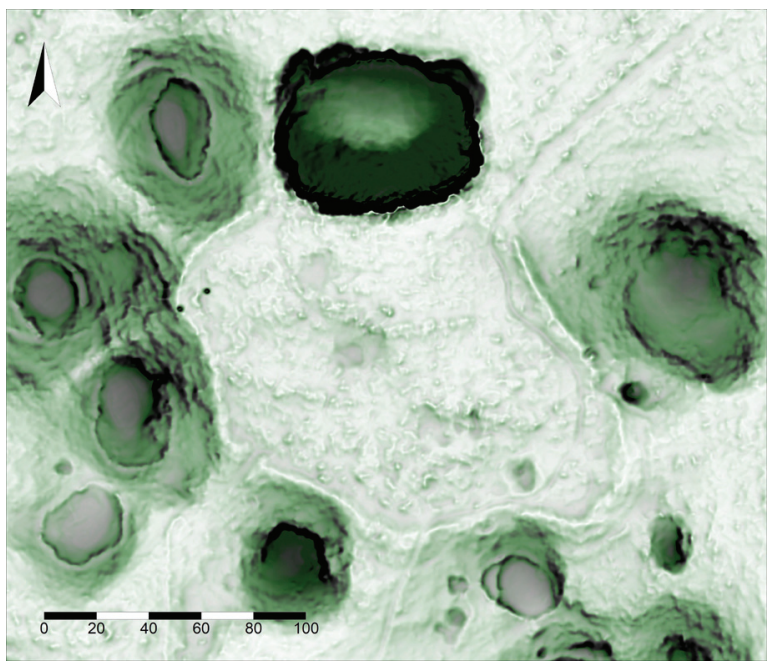

Na nekaterih mestih, predvsem $\mathrm{v}$ severnem in zahodnem delu gradišča, so ostanki obrambnega okopa še vedno dobro vidni, medtem ko so drugje že povsem zabrisani. Stanje je najslabše v južnem delu. Na splošno lahko rečemo, da je gradišče Debela griža zaradi naravne zaščite, ki mu jo nudijo vrtače, nekaj posebnega. Kljub bistveno manjšemu obsegu na nek način spominja na istoimensko gradišče v bližini Volčjega Grada. »Lepa krožna planjava« znotraj obrambnega okopa je v resnici zakrasela in posejana $\mathrm{s}$ skalami, zato ne deluje kot vabljiv kraj za poselitev. Tudi bližnja okolica je močno zakrasela in ne ravno rodovitna, saj so za poljedelstvo potencialno primerne le nekatere manjše doline. Iz tega bi bilo upravičeno domnevati, da so se na tem področju ukvarjali predvsem z živinorejo.

Slapšak (1995) domneva, da je bilo gradišče verjetno prvenstveno namenjeno nadzoru teritorija in ne bivanju. Najverjetneje je spadalo v vplivno območje gradišča na Ajdovščini (kota 804), ki je bilo precej pomembnejše. Vsekakor pa je zanimivo, da so na območju Debele griže našli arheološke ostanke, ki zavzemajo obdobje od pozne bronaste dobe pa vse do rimskega obdobja. To kaže, da je bilo gradišče vseeno pomembno in poseljeno res dolgo časa.

Jama, ki jo omenja Marchesetti, je znana kot Rodiška pečina (tudi Pečina v Remenšici oz. Pečina v Remeščici). Zaradi strmega terena je dostop do nje in do bližnjih spodmolov nekoliko težaven. Možno je sicer, da so jo v preteklosti izrabljali kot skrivališče, vendar bi bili ljudje, ki bi se v njej skrivali, v primeru obleganja istočasno ujeti v past. Dostopna pot je namreč samo ena. 


\section{Krvice (E Š D 17304)}

Najdbe skeletnih grobov kažejo na obstoj grobišča iz obdobja antike ali zgodnjega srednjega veka. Datacija: rimska doba, zgodnji srednji vek. Opis lokacije: arheološko najdišče obsega ledino Krvica zahodno od vasi in južno od stare poti $v$ vas.

Krvice se nahajajo na ravnini v neposredni bližini vasi Rodik. Tod je najverjetneje nekoč tekla cesta, ki je povezovala Rodik z Matarskim podoljem. Kljub temu da je celotno območje izrabljeno za kmetijske namene (travniki in njive), so še vedno vidne številne kamnite groblje in ravno v teh grobljah oz. v njihovi neposredni bližini so v preteklosti našli več okostij. To kaže, da je bilo na tej lokaciji nekoč grobišče.

Ustno izročilo pravi, da so na ledini Krvice nekoč našli tudi orožje, govori pa se tudi, da je tod pokopan Atila. Ko se je vračal domov čez Rodik, ga je pri kalu Bukovec pičila strupena kača in je umrl (Peršolja 2000, 173-174). Etnologinja in arheologinja Katja Hrobat Virloget je med svojimi raziskavami zabeležila sledeče pričevanje (2003, 158-159):

Stari ljudje so govorili, da je Atila pokopan na Krvicah. Na tem mestu naj bi bila bitka s Turki (tu naj bi Turke pričakali). Bilo naj bi dosti krvi, od tod tudi ime Krvice. Atila naj bi bil pokopan tu v treh »trugah«. In res je moj pranono šel s prijateljem kopat tam. Odkrila sta železje in kosti. Poklicali so župnika, da si pride ogledat. Moja mati je govorila, da so hranili najden kos "pleha" (pločevine) doma in da se je vedno svetil. Nikoli ga ni bilo potrebno čistiti kot ostalo železje, ki zarjavi. Mogoče je bil del skrinje. Predmet so čuvali kot posebno dragocenost. Večkrat so si ga prihajali ogledovat celo Tržačani. Žal je predmet izginil, verjetno so ga ukradli.

Že Bleiweis $(1859,273)$ je poročal o podobnih govoricah:

Njivam tistim pravijo »krivice«. Zakaj neki krivice. Ker krive niso, temuč lepo ravne? Morda je bila tam ob beneških ali turških vojskah kaka kervava bitva, po kteri so njive imenovali, in od kodar so še tiste kosti pod kamnjem ležale.

\section{Grubelce}

Ledina Grubelce (na nekaterih kartah tudi Grublje) se nahaja jugovzhodno od Rodika ob vznožju Krasiča (kota 675). Območje sicer ni uvrščeno v register kulturne dediščine, vendar je kljub temu zgodovinsko zanimivo. Tu 
namreč najdemo stara, deloma tudi terasirana polja, ki se danes izkoriščajo kot travniki. V preteklosti so tod našli fragmente tegul in keramike, ki najverjetneje izhajajo iz rimskega obdobja, vendar natančna datacija ni možna (Slapšak 1995). Prisotne so tudi številne kamnite groblje (od tod ime), na površini katerih je mogoče najti od ognja ožgane kamne. Zaradi oblike in razporeditve je malo verjetno, da gre pri grobljah za ostanke stavb. $\mathrm{Na}$ območju so prisotni tudi vojaški objekti novejšega datuma, med katerimi izstopa globok strelski jarek na severni strani, ki najverjetneje izvira iz obdobja prve svetovne vojne. Jarek je sicer povsem zaraščen $z$ vegetacijo, vendar je na lidarju dobro viden.

\section{Zgornji del poti po Mitskem parku Rodik \\ Tabor (E ŠD 7306)}

Ruševine (verjetno srednjeveškega) zidanega objekta in sledovi obzidja. Neraziskano. Datacija: srednji vek. Opis lokacije: arheološko najdišče obsega plato vzpetine Tabor severovzhodno od Rodika.

Tabor, med domačini znan tudi kot Robida, se nahaja na nadmorski višini 678 m skoraj točno nasproti gradišča na Gabrovi strani. O njem je pisal že Bleiweis (1859, 273):

Pa ozrimo se na hrib, v kterega večernem znožji Rodik leži. Iz vasi zapaziš tri verhe, kterih vsak svojo imenitost nosi. Severni najnižji se imenuje Tabor. Na njem se še poznajo razvaline stolpa, v kterem so se menda Rodičani Turkom branili.

Najdišče se nahaja na izpostavljeni točki slemena. Severno in južno pobočje je strmo, po samem slemenu pa poteka pot, ki povezuje Tabor s sedlom pod hribom Pungrat. Od tod se pot obrne proti severu in se nato položno spušča proti Kačičam. Kljub zaraščenosti so še vedno vidni ostanki starih teras, ki so se najverjetneje uporabljale za kmetijske namene. Tabor obdaja slabo ohranjen obrambni jarek, same razvaline manjšega utrjenega objekta pa v celoti prerašča trava. Območje je sicer spomeniško zaščiteno, vendar popolnoma neraziskano, zato je povsem možno, da je srednjeveška utrdba zrasla na osnovi nekega še starejšega objekta.

Domačinka Jasna Majda Peršolja (2000, 160) je zapisala sledečo zgodbo:

$\mathrm{Na}$ Robidi nad Rodikom je bil enkrat velik mogočen grad. Strela je udarila vanj in potlej se je zrušil. Za njim je ostalo merišče. V tistem merišču je bila velika lepa bela kača. Eni ljudje so rekli, da je kača črna 
in da je tisto zakleta grofica. Vsi so se kače bali in svarili otroke, ko so šli na Robido: „Varte se kače. V merišču je nevarno.»

Ustno izročilo tudi pravi, da so Tabor uporabili kot vir gradbenega materiala, deloma tudi za gradnjo številnih manjših vojaških objektov, ki so nastali tekom 20. stoletja.

\section{$\check{C}$ uk}

Čuk je 756 m visoka vzpetina, ki spada v širše spomeniško zaščiteno območje Ajdovščine (glej točko 8). Ta hrib je zaradi nenavadne naravne posebnosti že od nekdaj zavit $\mathrm{v}$ tančico skrivnosti. Na njem namreč najdemo majhno jezerce, okoli katerega so se spletle številne legende. Že Bleiweis (1895) je poročal:

Rodičani pripovedujejo, da je na tem verhu nekdaj jezero stalo, iz kterega se je poleti gosta megla valila, iz ktere je bila vselej toča, kadar se je zmešala z meglo ustajočo iz enacega jezera na večernih gričih. Hodili so nekdaj iz Brezovice na Jezero s procesijo ${ }^{6}$ jezero blagoslovljat. Nekteri pravijo, da zavolj omenjene megle, drugi pa zato, da bi se jezero ne razlilo s hriba po polji. Bodi si kar hoče; da ni prazna pravlica, priča brezovški katapan iz osemnajstega stoletja, v kterem se bere: "habet jus paludem benedicendi«, paludem pa imenuje tisto jezero. Kos kamna, pri kterem je bil blagoslov, se še vidi in na njem spodnji del rimskega križa vsekan. Spremljevavec je pravil, da še celi kamen pomni; pa kam so ga ljudje pripravili, se ne ve. Se ve da, ložej se verjame, da je bila tam le velika lokev, v kteri so blago napajali. Zdaj je vode malo v jezeru; raste pa po njem gosto bičje.

S Čukom se je ukvarjal tudi Marchesetti (1903, 79): ${ }^{7}$

Nad Rodikom se dviga z gozdom porasel hrib Čuk, na katerem se nahaja veliko gradišče. Tu pa tam je sicer še moč uzreti ostanke obrambnega okopa, vendar gosta vegetacija ne samo da ovira izvedbo natančnih meritev, ampak celo onemogoča, da bi sledil poteku okopa.

${ }^{6} \mathrm{O}$ tem, kako so potekale procesije, piše Matija Sila v svoji knjigi $(1882,42)$ : »Tudi tam je sjezeror (mala luža) na `Čuku<, kamor so v starih časih s procesijo hodili (bilo je neki do dvajset križnikov), da so hudobo zarotili: ,Gospodine! Zateri ga in ubi ga, onega vraga, ki tu prebiva!‘, kajti od ondi je prihajala večkrat nevihta.«

${ }^{7}$ Marchesetti gradišče poimenuje »castelliere sul monte Ciucco«; to je eno izmed redkih opisanih gradišč, ki jih Marchesetti ni skiciral. Iz italijanščine prevedla Alja Margon. 
Opravil sem manjši poskusni izkop, med katerim sem naletel na številne prazgodovinske črepinje in živalske kosti, pa tudi na fragmente rimskih amfor in provincialno samostrelno fibulo iz brona. Pred leti je kmet tod našel več posod in nekaj bronastih predmetov, ki pa so se izgubili.

Nenavadno je, da na Čuku še nihče do sedaj ni našel gradišča, ki ga opisuje Marchesetti. Njegov opis ne ustreza niti gradišču na bližnji 804 m visoki Ajdovščini, ki ga, zanimivo, raziskovalec sploh ne omenja.

Arheološke raziskave $\mathrm{v}$ 80-ih letih 20. stoletja pa so razkrile prisotnost kar treh različnih grobišč iz rimskega obdobja (Istenič 1987). Kot v mnogih drugih primerih so tudi tokrat arheološki izsledki potrdili to, na kar je opozarjalo že ljudsko izročilo. V Rodiku je bilo namreč vedno živo prepričanje, da je na Čuku pokopališče prvotnih prebivalcev Rodika (Hrobat 2005). Na vseh treh lokacijah so našli žgane grobove s številnimi grobnimi dodatki. V grobove so bile tako pridane keramične posode, oljenke in nakit, v najnižje ležečem grobišču pa so našli tudi orožje. Orožje je sicer v rimskih grobovih redek pridatek, vendar se je pri nekaterih podjarmljenih ljudstvih ta navada vseeno ohranila. Glede na to, da so v približno $10 \mathrm{~km}$ oddaljenem prazgodovinskem grobišču na Socerbu našli grobove $z$ orožjem, bi lahko sklepali, da je tudi pridajanje orožja v grobove Pod Jezerom običaj, ki izhaja iz lokalne prazgodovinske tradicije (Istenič 1987). Videti je torej, da so tod okoli živeči Rundikti (Slapšak 1977), kljub temu da so se romanizirali, vsaj v prvih stoletjih rimske dominacije še vedno ohranjali vsaj nekatere stare navade. Ravno grobni pridatki namreč omogočajo umestitev odkritih grobov v 1. in 2. stoletje n. št.

V neposredni bližini jezerca ${ }^{8}$ pa se skriva še ena skrivnost. Jasno se namreč vidi, da je vzhodna brežina utrjena in da gre pri tem za zelo star poseg. Za utrjevanje so bili uporabljeni veliki apnenčasti bloki, ki so bili, glede na to, da je okolica flišnata, več kot očitno prineseni od drugod (Slapšak 1997). Zakaj niso uporabili kar na kraju samem dostopnega materiala in čemu sploh služi zidana struktura, ki nima na videz nobene koristne funkcije, bo najverjetneje za vedno ostalo uganka. Le špekuliramo lahko, da je bilo tu v daljni preteklosti mogoče kultno mesto in da se je oddaljeni spomin na takratno dogajanje nekako predrugačil v zgodbe o lintverju (Hrobat 2003; 2004; Hrobat Virloget 2010).

\footnotetext{
${ }^{8}$ Po pričevanju domačina R. Lukovca je k izginjanju jezera še dodatno pripomogel močan potres marca 1928.
} 


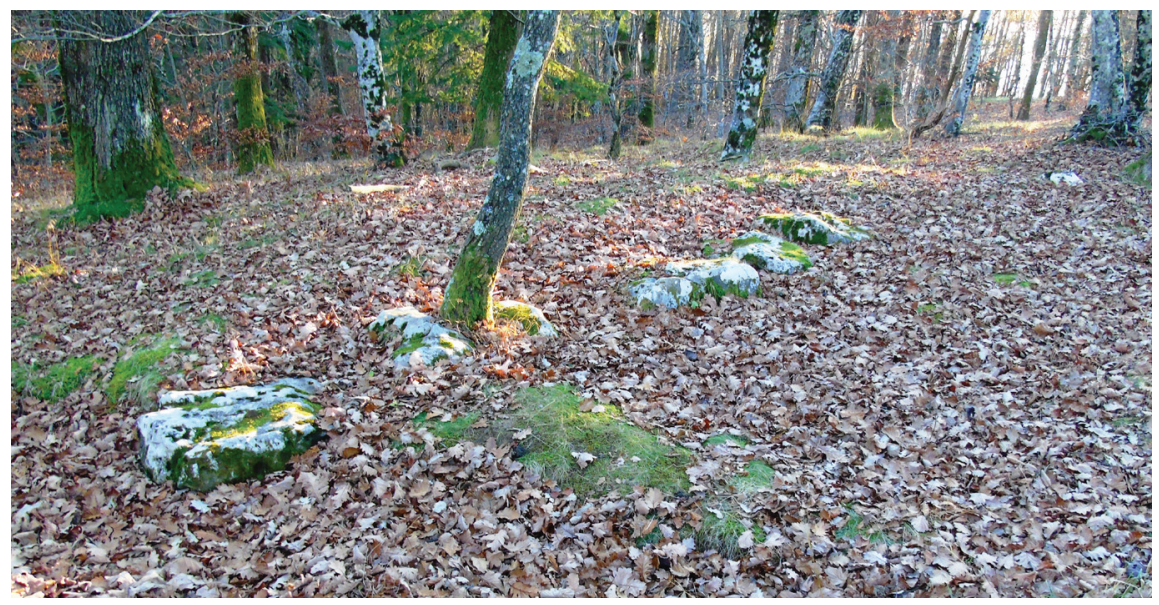

Slika 5 Apnenčasti bloki ob jezeru na Čuku (avtor fotografije Društvo Limes)

\section{Ajdovščina (E ŠD 624)}

Prazgodovinsko gradišče (domnevno središče Rundiktov) s kontinuiteto $v$ pozno antiko. Urbana zasnova znotraj monumentalnega obrambnega sistema. Odkriti tudi zgodnjerimski žgani grobovi. Datacija: železna doba, rimska doba. Opis lokacije: utrjena naselbina je na osamelem visokem hribu Ajdovščina. Zgodnjerimski grobovi so odkriti na Sedlu in Pod Jezerom.

"Ajdovci z Ajdovščine nad Rodikom so se razselili v Slope, Brezovico in Rodik. Na Ajdovščini je bilo šestintrideset do štirideset hiš. Ajdovci so se v Rodiku najprej naselili v Podluzo, kjer je dosti vode." (Hrobat 2003). »Velikani, ki so živeli na Ajdovščini, so bili bolj zategle kože in imeli so črne lase. Imeli so veliko mesto, okrog katerega je bilo velikansko obzidje s tremi velikimi vrati (zlata, srebrna in bronasta). Bili so dobri kovači." (Peršolja 2000, 42)

Ajdovščino je natančno opisal že Bleiweis (1859, 273-274):

Rodičani pripovedujejo, da je bilo na tem verhu nekdaj ajdovsko mesto, ktero so sovražniki razdjali in Ajde pomorili. Da ni vse to prazna pravlica, se lahko prepriča, kdor vidi »mirišče«, kakor Rodičani razvaline imenujejo. Kmet, ki je mene in častitega g. A. Martinčiča, duhovnega pomočnika v Rodiku, na Ajdovščino spremil, nama je nekdanje mesto popisoval, kakor bi ga bil z lastnimi očmi vidil. Tu so bile velike vrata, pravi, ko naji pripelje do mirišča na južni strani verha. Potem 
naji vodi po oklepu, kterega razvaline pričajo, kako jako zavarovano je bilo mesto. Kakih petsto korakov dalječ od velikih vrat pridemo do kota, kjer se oklep bolj proti severju zavije; tu nama kmet kaže lego kovačije in spriča resničnost svoje povesti $\mathrm{z}$ žlindro, ktere se obilo najde znotraj in zvunaj oklepa. Na severnem koncu, velikim vratam ravno nasproti, je stal velik stolp, kolikor se iz razvalin razvidi. Manji vrata so menda deržale na levi strani stolpa po robu na Tabor; druge pa pred kovačijo proti jutru, kjer so Ajdje, po pripovesti kmetovi, po zmernih rebrih polje in nograde imeli. Večerna stran ni bila menda s tako debelim zidom zavarovana, ker razvaline so veliko manje; pa tudi ni bilo treba, ker hrib je tam zlo sterm. Skoraj sred mirišča nama je kmet pokazal mesto, kje da je podzemeljski hram. Če se o mokrotnem vremenu po tistem prostoru malo poskoči, pravi, šošnja, kakor da bi po kakem obočju skakal. Mesto je bilo podolgasto okroglo od juga proti severju, v ktero stran je tudi vstajalo, tako, da je omenjeni stolp na najvišjih tleh stal.

Na podoben način Ajdovščino opiše tudi Rutar dobra tri desetletja kasneje $(1859,215)$ : »Če zasledujemo to zidovje, spoznamo koj, da je bila tudi rimska naselbina še zelo obsežna in dobro utrjena. Poznajo se še dobro vhodna vrata, stolpi, kleti, kovačnice z žlindro itd. Okoli in okoli pa so že našli mnogo črepinj, sulic in pušic, tudi denarja itd.« Je pa iz njegovega zapisa moč razbrati tudi to, da so do tega kraja domačini čutili neko strahospoštovanje (Rutar 1859, 215): »Ljudstvo veruje, da velikanska kača varuje zaklade, ki so zakopani na Ajdovščini. Nikomur pa ni svetovati, da bi sam tam kopal.«

Kljub vsemu pa je do prvih pravih arheoloških raziskav prišlo šele v drugi polovici 20. stoletja. Ugotovljeno je bilo, da je na vrhu Ajdovščine (804 m) stalo dobro utrjeno naselje, ki je sicer nastalo v železni dobi, a je bilo neprekinjeno poseljeno tudi skozi celotno rimsko obdobje, vse do pozne antike. Na 3,8 ha veliki ravnici znotraj obzidja najdemo ostanke približno tridesetih objektov. Večinoma je šlo za bivališča, najdemo pa tudi obrtne delavnice, kot je prej omenjena kovačija. Ocenjuje se, da je imelo naselje približno 500 prebivalcev. V bližini najvišje točke gradišča so vidni tudi ostanki velike stavbe $\mathrm{z}$ apsido, za katero se je sprva domnevalo, da gre za cerkev. Med izkopavanji so sicer arheologi naleteli na številne kovinske predmete (predvsem orožje in orodje), opazili pa so tudi sledi močnega požara (Slapšak 1997).

Ajdovščina je bila torej dolgo časa pomembno središče za okoliško pre- 


\section{Slika 6}

Lidarski posnetek Ajdovščine

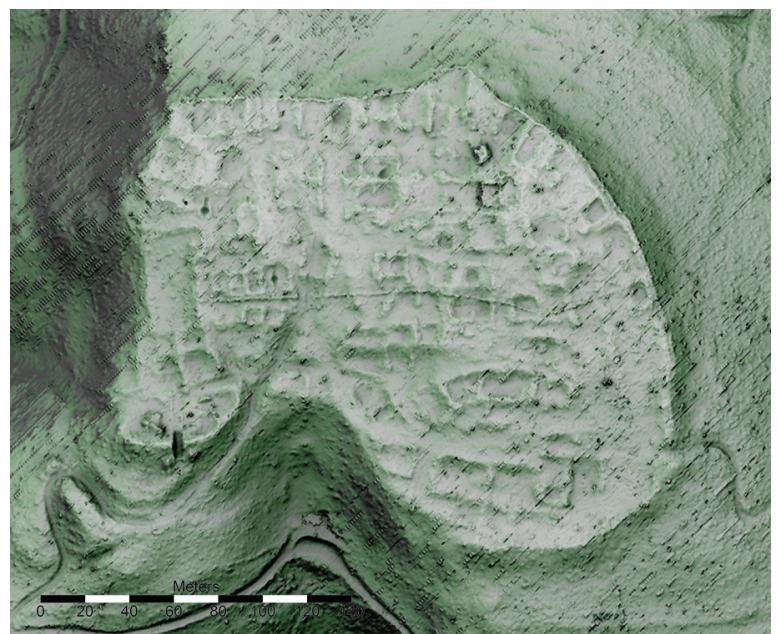

bivalstvo, tj. Rundikte, ki jim zaradi kompleksnih vprašanj ne znamo pripisati etnične pripadnosti. Po rimski osvojitvi, do katere je najverjetneje prišlo proti koncu 2. stoletja pr. n. št., so najverjetneje vsaj deloma opustili svoja višinska utrjena naselja in začeli poseljevati tudi ravninska področja. Tako so nastala antična naselja kot tisto na lokaciji Pod Lipami, (E Š D: 7312), poštna postaja Ad Malum in druga. Pomembno vlogo je pri tem imelo tudi razvejano rimsko cestno omrežje (Slapšak 1995; 1997). ${ }^{9}$

Ravno rimskim cestam se gre zahvaliti za edino antično omembo teh krajev. Leta 1842 so pri Materiji našli rimski napisni kamen ${ }^{10} \mathrm{~s}$ sledečim zapisom v latinščini:

(H)anc viam derectam per Atium centurion(em) post sententiam dictam ab A Plautio legato Ti Claudi Caesaris Aug(usti) Germ(anici) et postea translatam a Rundictibus in fines $C$ Laecani Bassi restituit iussu Ti Claudi Caesaris Aug(usti) Germ(anici) imperatoris L Ruffelius Severus primiplaris.

Zapis govori o uspešno rešenem sporu med rimskim veleposestnikom Gajom Lekanijem Basom in avtohtonimi prebivalci Rundikti. Do spora je prišlo zaradi meje med posestvi in pravice do koriščenja lokalnih cest

${ }^{9}$ Po Matarskem podolju je tekla t. i. via Tarsatica, ki je povezovala Tergeste (Trst) in Tarsatico (Reka).

${ }^{10}$ Napisni kamen iz Materije hrani Mestni muzej za zgodovino in umetnost v Trstu (Museo Civico di Storia ed Arte di Trieste), v Rodiku pa je moč videti njegovo kopijo. 
(Vidrih-Perko 2006). Upravičeno je torej domnevati, da je današnji Rodik ime dobil ravno po nekdanjih prebivalcih tega območja.

$S$ krizo rimskega imperija in nasilnim dogajanjem, ki je spremljalo njegov zaton, so ogroženi prebivalci začeli opuščati izpostavljene nižinske naselbine in se znova zatekati na višje ležeče predele. Postopoma so obnovili stara utrjena naselja in postavili tudi nova. V tem kontekstu Ciglenečki (2015) domneva, da je Ajdovščina zopet pridobila na veljavi kot pomembno središče v zaledju zapornega sistema Claustra Alpium Iuliarum. Njena lega je namreč nenadoma postala izrazito strateška, saj je omogočala nadzor nad nekaterimi potmi, ki so vodile s severa proti Istri in Dalmaciji in $\mathrm{z}$ vzhoda proti Italiji.

Zagotovo so prvi slovanski prišleki tukaj še vedno našli avtohtone prebivalce, ki so jih poimenovali Ajdi (Ciglenečki 1997). Če je verjeti ljudskemu izročilu, so se staroselci in prišleki med seboj postopoma začeli mešati, dokler se staroselci niso popolnoma asimilirali. Zaradi izboljšanih varnostnih razmer je prišlo tudi do dokončne opustitve utrjenih višinskih naselij. $\mathrm{Na}$ ostankih nekaterih so nato v srednjem veku zrasli gradovi kot npr. Sv. Križ (E Š D: 17841) pri Slopah ali Završnik (E Š D: 7303) pri Podgradu pri Vremah, mogoče tudi Kačiče. Je pa zato v bližini opuščenih starih nastala na lažje dostopnih območjih cela vrsta novih naselij, kot so Rodik, Slope, Brezovica, Artivže, Podgrad pri Vremah in druga.

\section{Njivice/Vrhule}

»Na hribih okoli so bili še trije majhni gradovi - ajdovščine (ajdušne). Eden je bil na Verhulah nad Rodikom, drugi je bil na Selnicah na Pristavi in tretji v Borštu nad Potokom. S tistih gradičev se je videlo proti Istri, Trstu, Krasu in Pivki.« (Kerševan in Krebelj 2003, 138-139)

Ledini Njivice in Vrhule se nahajata na slemenu med Ajdovščino in Artvižami. Flišnat teren, zavetrje, majhen naklon in prisotnost nekaterih izvirov so omogočili nastanek zaselkov in izrabo površin za kmetijske namene. $\mathrm{Na}$ terenu so tako opazne številne terase.

$\mathrm{Na}$ Njivicah (716 m) se malo nad zgornjo teraso nahaja kamnita groblja, ki je dolga kakšnih 20, široka pa kakšne 4 metre. Arheološko je to področje sicer še popolnoma neraziskano, vendar je arheologinja Nada Osmuk med terenskimi ogledi zabeležila sledeče pričevanje: »Na ledini Njivce, ob stari poti iz Rodika na Artviže, naj bi bilo pokopališče Ajdov« ${ }^{11}$ Kot se pogosto dogaja, pa zna ljudsko izročilo povedati tudi drugačno zgodbo. Po tej naj

${ }^{11}$ Elaborat ZVN KD Nova Gorica ni javno dostopen. Citat povzet po Hrobat (2003). 
bi na Njivicah nekoč stalo naselje: »Rodik je bil prej na Njivicah. Danes so vidne ruševine.« (Hrobat 2003, 66)

Prebivalci Brezovice znajo o Vrhulah povedati marsikaj: „Starejši so pripovedovali, da so se Brezovčani priselili iz Vrhulj, to je sleme med Artvižami in Ajdovščino." (Hrobat 2003, 66). Vrhule je bežno raziskal in opisal Slapšak (1995), ki domneva, da je tam stalo rimskodobno naselje. Leta 1995 seveda še niso imeli na voljo lidarja, ki pa nam prav v primeru Vrhul postreže s celo serijo zanimivih ugotovitev. Poleg že s prostim očesom dobro vidnih ostankov več zgradb ${ }^{12}$ smo člani društva Limes na lidarju opazili, da se v smeri proti Brezovici na nadmorski višini približno $720 \mathrm{~m}$ nahaja večja krožna struktura, katere dejansko prisotnost smo preverili tudi na terenu. Krožna struktura ima kamnit obod premera približno $120 \mathrm{~m}$ in se nahaja tik ob robu, od koder se teren strmo spušča proti Brezovici; torej je bila s te strani dobro zaščitena. V bližini izvira potok Štuki, ki je lahko predstavljal vir pitne vode. Ugotavljanje, iz katerega obdobja izvira ta struktura in kakšen je bil njen namen, prepuščamo strokovnjakom. Glede na lego ob robu strmine bi lahko upravičeno domnevali, da je imela neko obrambno funkcijo. Mogoče gre za enega izmed gradov - ajdovščin, o katerih govori ljudsko izročilo?

\section{Križen drev (E ŠD 17290)}

Časovno neopredeljiva utrjena postojanka, ohranjena kot groblja na platoju z maltnim vezivom in obdelanimi kamni. $V$ izročilu je to bila postaja ob stari poti iz Rodika na Artviže. Datacija: rimska doba, srednji vek. Opis lokacije: Arheološko območje obsega vrh slemenskega hrbta, severozahodno od Artviž.

Križen drev (na nekaterih kartah tudi Križni drev ali Križandrev) leži na slemenu, ki povezuje Ajdovščino in Artviže. Ob sami poti najdemo tudi star mejnik, ki je označeval tromejo med občinami Rodik, Artviže in Podgrad pri Vremah. Po slemenu poteka cesta, severno od nje pa na koti 797 leži obsežna kamnita groblja, ki v sebi skriva ostanke manjše utrdbe. Domačini so ta kraj seveda poznali, zato je našel svoje mesto tudi v ustnem izročilu. V groblji se tako nahaja skrit zaklad, ki pa ga varuje kača (Hrobat 2003).

Ker je območje še neraziskano, lahko o starosti le ugibamo. Glede na ostanke malte Slapšak (1995) domneva, da gre za antični ali srednjeveški

\footnotetext{
${ }^{12}$ Pri površinskem pregledu najbolje ohranjenih delov nismo opazili ostankov malte, torej je povsem možno, da je šlo za suhozidno gradnjo.
} 


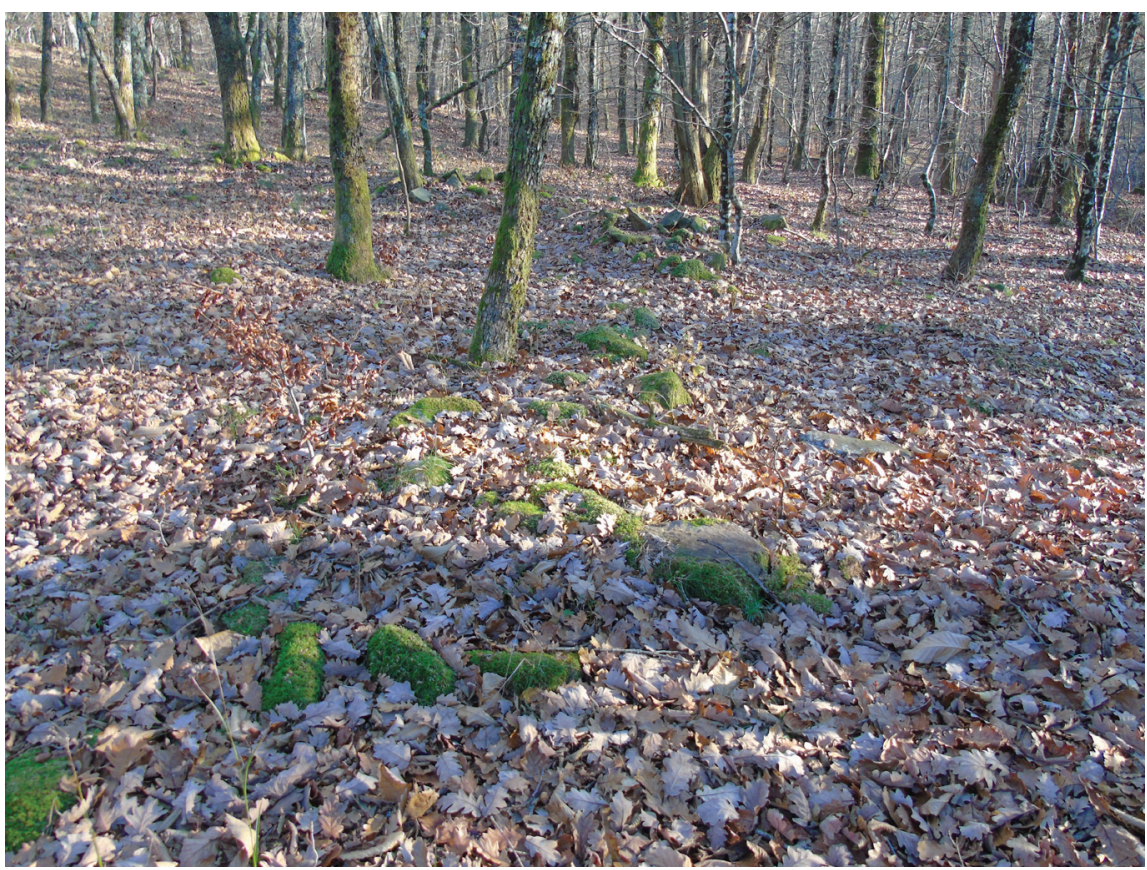

Slika 7 Ostanki kamnite konstrukcije na Vrhulah (avtor fotografije Društvo Limes)

objekt. Dostop do utrdbe je bil možen samo po slemenu, saj sta tako južno kot severno pobočje zelo strma. Če ne bi bilo gozda, bi bil razgled zelo dober, saj bi se proti severu videlo vse do doline reke Reke, proti jugu pa bi bil možen dober nadzor Matarskega podolja.

\section{Pristava}

Arheološko sicer neraziskana Pristava je v ljudskem izročilu pustila veliko sledi. Poleg tega, da je to ena izmed lokacij, kjer naj bi stale »ajdušne« (glej točko 9), naj bi po drugi zgodbi tod stalo tudi naselje: »Podgrad pri Vremah je bil najprej na Pristavi, kakor imenujejo domačini grič nad Podgradom (proti zahodu). Tam so namreč živeli majerji, to so grofovi hlapci. Še danes so ohranjena imena, kot so vrtovi, žardin ... Na vrhu Pristave, na zahodnem delu, so še danes vidne groblje." (Hrobat 2003, 59). Domačini vedo povedati tudi to, da so tam še vedno dobro vidne ograde, ki so bile namenjene varovanju grofovih ovc (Kerševan in Krebelj 2003).

Vidimo torej, da je tudi pri ljudskem izročilu o Pristavi viden dualizem utrdba - naselje, ki ga v končni fazi lahko potrdimo tudi na terenu. »Ajdušno« bi tako lahko iskali na vršni koti 635, ki je v Franciscejskem katastru 


\section{Slika 8}

Lidarski posnetek Pristave

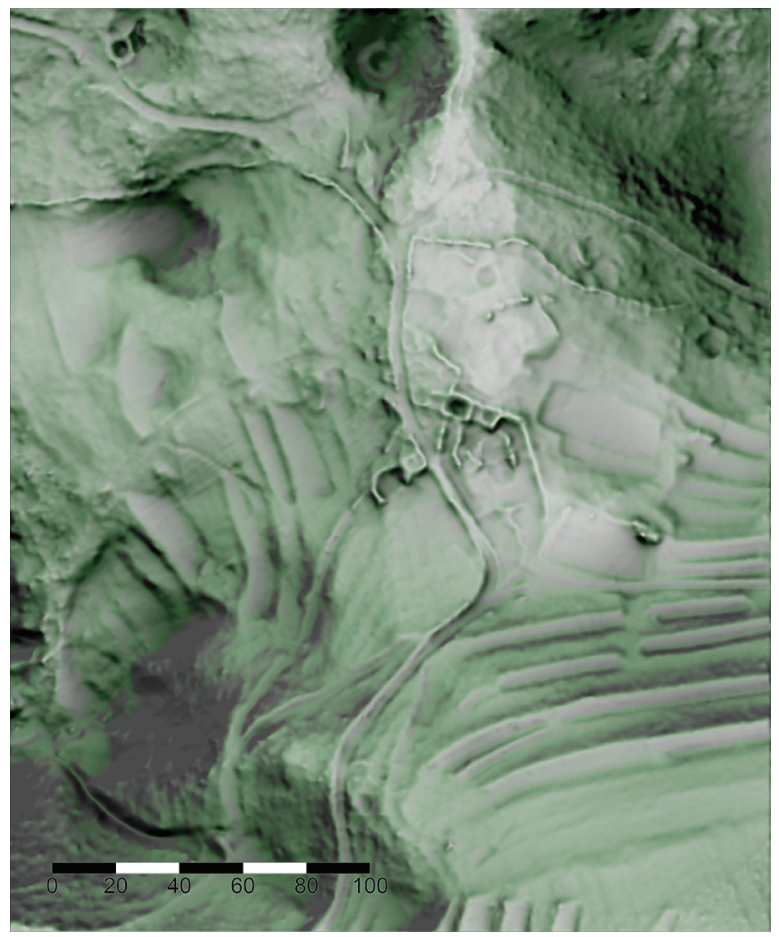

označena kot »Prestava grofova«, naselje pa bi lahko umestili na kakšno 200 m oddaljeno nižje ležečo lokacijo (kota 594), ki v moderni topografiji nosi ime Graje. Na koti 635 je vidnih več grobelj, vendar je brez arheoloških raziskav nemogoče reči, ali gre za ostanke obrambnih ali bivalnih struktur. Vsekakor pa bi v prid prisotnosti »ajdušne« govoril dober razgled s te točke.

Po drugi strani pa je zaradi lege na položnem delu grebena mogoče povsem mirne duše izključiti kakršno koli vojaško vlogo ostankov na Grajah in potrditi kmetijsko vlogo, ki jo Pristavi pripisuje ljudsko izročilo. Tod je možno opaziti obsežne ostanke antropogenih struktur, ki pa so popolnoma razvaljene. Iz lidarskih posnetkov je kljub temu možno razbrati tlorise vsaj treh objektov. Obrambnih struktur, kot so nasipi ali jarki, ni. Brez arheoloških izkopavanj natančna datacija seveda ni možna, bi si pa upali domnevati, da gre za obdobje srednjega veka, če ne še za pozno antiko, vsaj kar se ostankov na koti 635 tiče. O možnem obstoju serije višinskih utrdb, razporejenih vzdolž brkinskih slemen, ki so v nemirnih poznoantičnih časih nudile zaščito okoliškim prebivalcem, nenazadnje govori tudi Slapšak (1995). 
Slika 9

Lidarski posnetek Mešuc

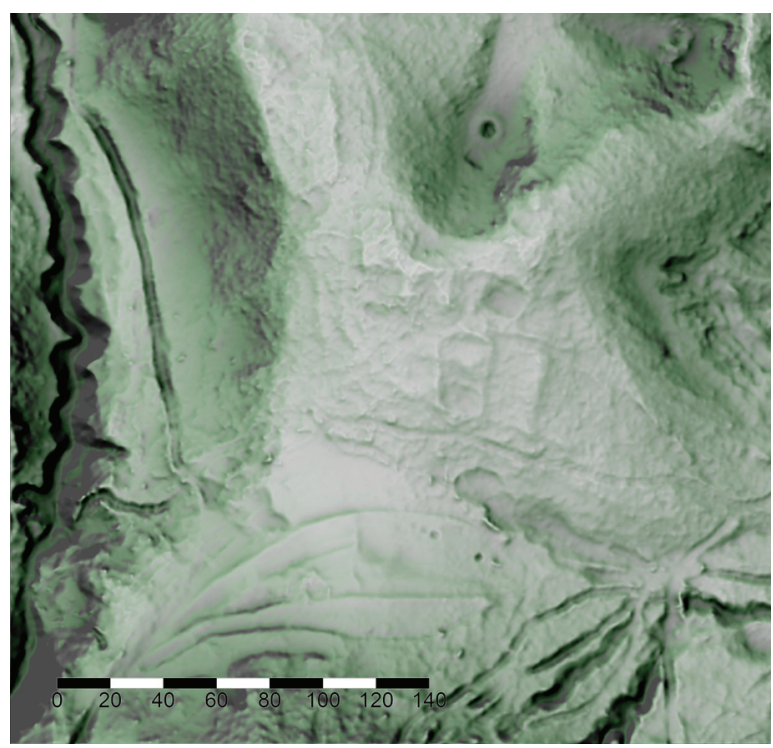

\section{Mešuce - fosilna polja}

Toponim Mešuce označuje planotasto vzpetino (519 m), ki leži približno 1 km severovzhodno od Ajdovščine. Lokacijo v ta sestavek uvrščamo kljub temu, da o njej ne govorijo ne pisni ne ustni viri. Vzrok temu je lidarski posnetek, ki na tem območju razkriva prisotnost številnih fosilnih polj. Med terenskim ogledom smo opazili ostanke treh ograd. To je nedvoumen znak, da se je nekoč v preteklosti na tem območju vršila kmetijska dejavnost. Zelo verjetno so poleg opaženih struktur stali tudi bivalni objekti, od katerih pa ni ostalo nič. Skupaj s Pristavo je to edina severno od slemena med Ajdovščino in Rodikom ležeča lokacija, kjer so opazne sledi kmetijske izrabe v preteklosti.

\section{Literatura}

Bleiweis, J. 1859. »Ozir po domovini: Rodik in pa Ajdovščina nad Rodikom.» Novice gospodarske, obertniške in narodne, 31. avgust.

Ciglenečki, S. 1997. "Strukturiranost poznorimske poselitve Slovenije.« Arheološki vestnik 48:191-202.

- 2015. "Late Roman army, Claustra Alpium Iuliarum and the Fortifications in the South-Eastern Alps/Poznorimska vojska, Claustra Alpium Iuliarum in utrjena krajina v jugovzhodnih Alpah."V Evidence of the Roman army in Slovenia/Sledovi rimske vojske na Slovenskem, ur. J. Istenič, B. Laharnar in J. Horvat, 385-430. Ljubljana: Narodni muzej Slovenije. 
De Marchesetti, C. 1903. I castellieri preistorici di Trieste e della Regione Giulia. Trst: Italo Svevo.

Istenič, J. 1987. »Rodik - grobišče pod Jezerom. "Arheološki vestnik 38:69136.

Hrobat, K. 2003. „Šembilja na rimskih cestah: o ustnem izročilu in arheoloških raziskavah.« Diplomsko delo, Univerza v Ljubljani.

—. 2004. »Ustno izročilo o lintverju kot indikator ritualnega prostora antične skupnosti Ajdovščine nad Rodikom. «Studia mythologica Slavica $7: 63-78$.

—. 2005. "Ajdi z Ajdovščine nad Rodikom. "Studia mythologica Slavica 8:99-112.

- 2010. Ko Baba dvigne krilo: prostor in čas v folklori Krasa. Ljubljana: Znanstvena založba Filozofske fakultete.

Kerševan, N., in M. Krebelj. 2003. Düša na bicikli: folklorne pripovedi iz Brkinov, doline Reke in okolice. Zbirka Glasovi 27. Ljubljana: Kmečki glas.

Mlekuž, D. 2012. "Messy Landscapes: Lidar and the Practices of Landscaping."V Interpreting Archaeological Topography: Lasers, 3D Data, Observation, Visualisation and Applications, ur. R. S. Opitz in D. Cowley, 90101. Oxford: Oxbow.

Peršolja, J. M. 200o. Rodiške pravce in zgodbe. Ljubljana: Mladika.

Rutar, S. 1895. "Završniška gospoščina na Krasu.«Izvestija Muzejskega društva za Kranjsko 5 (6): 213-228.

Sila, M. 1882. Trst in okolica: zgodovinska slika. Trst: Edinost.

Slapšak, B. 1977. "Ad C I L 5, 698 (Materija): Via derecta - translata (in fines alicuius) - restituta."Arheološki vestnik 28:122-128.

—. 1995. Možnosti študija poselitve v arheologiji. Arheo 17. Ljubljana: Slovensko arheološko društvo.

- 1997. "Starejša zgodovina Rodika."V Rodik med Brkini in Krasom: zbornik ob 350. letnici cerkve, ur. M. Pregelj, 19-61. Koper: Ognjišče.

Vidrih-Perko, V. 2006. »Razlaga rimskega napisa z Rodika v smislu nasprotujočih si interpretacij.«Annales: series historia et sociologia 16 (2): 443-452.

\section{Arheologija spomina: primer Rodika}

$\mathrm{V}$ tem sestavku predstavljamo znana in potencialna arheološka najdišča $\mathrm{v}$ okolici Rodika (občina Hrpelje-Kozina) ter analizo in elaboracijo javno dostopnih lidarskih posnetkov tega območja. Opisi in ugotovitve glede posameznih lokacij so rezultat skrbnih kartografskih, bibliografskih in neinvazivnih terenskih raziskav. Pri slednjih smo se osredotočili predvsem na lokacije, ki se nahajajo znotraj Mitskega parka Rodik in ki so našle svoje mesto tudi v ljudskem izročilu. Starost obravnavanih najdišč zaobjema resnično obsežno časovno obdobje, tj. od predzgodovine pa vse do srednjega veka. Objekti, ki so stali na obravnavanih lokacijah, se poleg starosti razlikujejo 
tudi po funkciji, ki so jih imeli v času nastanka: tj. obrambno, ekonomsko, bivalno ali razmejevalno. Včasih je resnično težko potegniti mejo in določiti točno starost ter funkcijo nekega objekta, saj sta je tako njegova oblika kot tudi funkcija skozi čas spreminjali. Videti pa je, da vsaj od železne dobe dalje vsi ti različni kulturni sloji niso bili nujno tudi posledica sprememb v populaciji. Tako arheološke raziskave kot ljudsko izročilo namreč nakazujejo, da se je na tem območju avtohtono prebivalstvo (s strani Rimljanov označeni za Rundictes, kasneje pa tradicionalno poznani kot Ajdi) obdržalo tudi po rimski osvojitvi, da pa so se domačini seveda postopoma romanizirali. Središče Rundiktov je bila nedvomno Ajdovščina (kota 804), od koder so vsaj do pozne antike nadzorovali obsežno območje Brkinov in Matarskega podolja. Že samo število najdišč dokazuje, da so Rundikti na tem območju pustili globok pečat. Pokrajino so oblikovali in preoblikovali tako $\mathrm{z}$ gradnjo utrjenih naselji na izpostavljenih vrhovih in s terasiranjem pobočij kot tudi s kasnejšo gradnjo naselij v nižinah. Po ustnem izročilu so v zgodnjem srednjem veku Ajdi dokončno opustili svoja višinska naselja in v dolini sezidali številne vasi, med njimi tudi Rodik. Zgodovinskih virov, ki bi to potrjevali, ni, saj se v arhivih na žalost ni ohranil noben pisni dokument. Ljudskega izročila ne more (za zdaj) potrditi niti arheologija, saj so arheološke najdbe iz tega "prehodnega« obdobja redke. Kar se materialnih dokazov tiče, je seveda še veliko za postoriti. Veliko je že popisanih in novoodkritih arheoloških najdišč, ki bi lahko marsikaj razjasnila, vendar ostajajo neraziskana. V pričakovanju novih raziskav in odkritij torej vprašanje o izginotju Rundiktov ali njihovem zlitju z zgodnjesrednjeveškimi slovanskimi prišleki puščamo brez odgovora.

\section{Archaeologies of Memory: The Case of Rodik}

In this article, we describe all known archaeological sites and potential archaeological areas in the surroundings of Rodik (Municipality of HrpeljeKozina), as well as the analysis and elaboration of L I D A R images available to the public for this area. Descriptions and findings related to particular locations are the results of careful cartographic, bibliographic, and non-invasive field research. During the above-mentioned research, we mainly focused on the locations within the Mythical Park Rodik, which feature prominently in the local folklore. The sites described can be dated back to different periods, from prehistory to the Middle Ages, an impressively extended period of time. Apart from their different age, the structures found at the locations also differ in the purpose they were built for, i. e. defensive, economic, residential, or as a land demarcation system. Sometimes it is really difficult to determine with absolute certainty the exact age and purpose of a structure because both its shape and function have changed over time. However, it seems that at least since the Iron Age all these different cultural strata have not necessarily been the result of changes in the population which inhabited the area. Both archaeological research and folk tradition indicate 
that the indigenous inhabitants of this area (which the Romans called Rundictes and later were traditionally known as Ajdi), were settled here even after the Roman conquest, after which the locals gradually became Romanised. The central settlement of Rundictes was undoubtedly Ajdovščina (hilltop, el. 804), from where, at least until the later years of antiquity, they controlled a large area of Brkini and Matarsko Podolje. The large number of sites proves that Rundictes left a deep mark in this area. The landscape was shaped and reshaped by the construction of fortified settlements on exposed peaks and terraced slopes, as well as by the later construction of settlements in the lowlands. According to oral tradition, in the early Middle Ages the Ajdi eventually left their mountain settlements and founded numerous villages in the valley, among them Rodik. Unfortunately, there are no historical sources that confirm this because no written document has been preserved in the archives. The folk tradition cannot be confirmed (so far) by archaeology either, because archaeological findings from this 'transitional' period are rare. As for the physical evidence, of course, much remains to be done. There are already numerous listed and newly discovered archaeological sites that could shed light on many facts, but they are still unexplored. Therefore, in anticipation of new research and discoveries, we leave unanswered the question whether the Rundictes died out or were assimilated by early medieval Slavic newcomers.

\section{Arheologija pamćenja: Primjer rodika}

U ovom članku predstavljamo od ranije poznata i potencijalna arheološka nalazišta u okolici Rodika (općina Hrpelje-Kozina) te analizu i razradu javno dostupnih lidarskih snimaka ovog područja. Opisi i nalazi u vezi s pojedinim lokacijama rezultat su pažljivih kartografskih, bibliografskih i neinvazivnih terenskih istraživanja. Tijekom navedenih istraživanja uglavnom smo se fokusirali na lokacije smještene unutar Mitskog parka Rodik koje su pronašle svoje mjesto u narodnoj tradiciji. Starost razmatranih nalazišta pokriva realno, opsežno vremensko razdoblje, tj. od prapovijesti do srednjeg vijeka. Osim po starosti, objekti koji su se nalazili na predmetnim lokacijama razlikuju se i po svojoj funkciji u vrijeme nastanka, tj. obrambenoj, gospodarskoj, stambenoj, ili funkciji razgraničenja. Ponekad je zaista teško povući crtu i odrediti točnu starost i funkciju nekog objekta jer su se i njegov oblik i funkcija s vremenom mijenjali. Ipak, čini se da barem od željeznog doba svi ti različiti kulturni slojevi nisu nužno bili rezultat promjena u populaciji. I arheološka istraživanja i narodna tradicija ukazuju na to da se autohtono stanovništvo na ovom području (koje su Rimljani nazivali Rundictes, a kasnije su bili poznati u narativnoj tradiciji kao ajdi) ovdje održalo i nakon rimskog osvajanja, ali su se starosijedioci postupno romanizirali. Središnje naselje Rundikta nedvojbeno je bila Ajdovščina (kota 804), odakle su, barem do kasne antike, kontrolirali veliko područje Brkina i Matarskog podolja. Već 
i sam broj nalazišta dokazuje da su Rundikti ostavili dubok trag na ovom području. Krajolik je oblikovan i preoblikovan gradnjom utvrđenih naselja na izloženim vrhovima i terasastim padinama, kao i kasnijom izgradnjom naselja u nizinama. Prema usmenoj predaji, u ranom srednjem vijeku ajdi su napustili svoja visinska naselja i u dolini osnovali brojna sela, među njima i Rodik. Ne postoje povijesni izvori koji to potvrđuju jer, nažalost, u arhivima nije sačuvan nijedan pisani dokument. Narodnu tradiciju ne može (za sada) potvrditi niti arheologija jer su arheološki nalazi iz ovog "prijelaznog« razdoblja rijetki. Što se tiče materijalnih dokaza, naravno, još treba puno toga učiniti. Postoje već brojna popisana i novootkrivena arheološka nalazišta koja bi mogla razjasniti mnoge činjenice, ali ona i dalje ostaju neistražena. Stoga, u iščekivanju novih istraživanja i otkrića, pitanje nestanka Rundikta ili njihovog stapanja s ranosrednjovjekovnim slavenskim došljacima ostavljamo bez odgovora. 